J. Dairy Sci. 100:8165-8169

https://doi.org/10.3168/jds.2017-13087

Crown Copyright $\odot$ 2017. Published by FASS and Elsevier Inc. on behalf

of the American Dairy Science Association ${ }^{\circledR}$. All rights reserved.

\title{
Short communication: Effect of fatty acid supplements on apparent ruminal synthesis of $B$ vitamins in lactating dairy cows
}

\author{
D. S. Castagnino, ${ }^{*} \dagger^{1}$ K. J. Harvatine,$\ddagger^{2}$ M. S. Allen, $\ddagger$ R. Gervais, $\dagger$ P. Y. Chouinard, $\nmid$ and C. L. Girard ${ }^{* 3}$ \\ ${ }^{*}$ Agriculture and Agri-Food Canada, Sherbrooke Research and Development Centre, 2000 College, Sherbrooke, QC, Canada, J1M 0C8 \\ †Département des Sciences Animales, Université Laval, 2425 rue de l'Agriculture, Québec, QC, Canada, G1V 0A6 \\ ‡Department of Animal Science, Michigan State University, East Lansing 48824-1225
}

\begin{abstract}
The effect of fat supplements (FS) providing different proportions of saturated (SFA) and unsaturated (UFA) fatty acids on supply, apparent ruminal synthesis (ARS), and duodenal flow (DF) of some B vitamins (thiamine, riboflavin, niacin, vitamin $\mathrm{B}_{6}$, folates, and vitamin $\mathrm{B}_{12}$ ) were evaluated in an experiment using 8 ruminally and duodenally cannulated lactating Holstein cows. The experiment was a replicated $4 \times 4$ Latin square design with 21-d treatment periods. The 4 treatments were a control diet without fatty acid supplement and 3 diets with $2.5 \%$ additional fatty acids from supplements containing (1) SFA, (2) an intermediate mixture of SFA and UFA, or (3) UFA. All diets were served as a total mixed ration once daily at $115 \%$ of the expected intake. B-vitamin concentrations were analyzed in feed and duodenal digesta. Apparent ruminal synthesis of each B vitamin was calculated as the DF minus the intake. B-vitamin concentrations were similar among the 4 treatments; consequently, daily intake of the vitamins followed the same pattern as dry matter intake. Adding FS decreased B-vitamin intakes (except vitamin $\mathrm{B}_{12}$ ), as did increasing the proportion of UFA. Riboflavin and niacin DF and ARS, expressed as total daily amount or per unit of dry matter intake, were not affected by FS, but increasing the proportion of UFA decreased riboflavin and niacin DF and ARS. Fat supplements decreased DF of vitamin $\mathrm{B}_{6}$, expressed either as total daily amount or per unit of dry matter intake. No treatment effects were observed on total daily folate DF and ARS. However, when expressed per unit of dry matter intake, folate DF and ARS were greater when

Received April 27, 2017.

Accepted June 18, 2017.

${ }^{1}$ Current address: Centre for Nutrition Modelling, Department of Animal and Poultry Science, University of Guelph, 50 Stone Road East, Guelph, ON, Canada, N1G 2W1.

${ }^{2}$ Current address: Penn State University, 301 W. Henning Bldg., University Park, PA 16802.

${ }^{3}$ Corresponding author: Christiane.Girard@agr.gc.ca
\end{abstract}

cows were fed FS and they increased linearly with the proportion of UFA in the supplement. Inclusion of fat supplements into the dairy cow diet had a limited effect on the fate of most B vitamins in the rumen although increasing the proportion of UFA in the FS linearly decreased apparent synthesis of riboflavin and niacin in the rumen and the amounts of these vitamins reaching the small intestine.

Key words: dairy cow, B vitamin, fatty acid, duodenal flow

\section{Short Communication}

Bechdel et al. (1928) demonstrated that B vitamins are produced by microorganisms present in the rumen. Consequently, B-vitamin supply for dairy cows is the summation of the amounts of vitamins from dietary sources escaping degradation in the rumen and the amounts of vitamins synthesized in the rumen. It is likely that B-vitamin supply is affected by the dietary ingredients themselves as well as their effects on rumen fermentation. However, research aiming to quantify the effect of diet composition on B-vitamin supply for dairy cows is very limited. Fat supplements (FS) are commonly used to increase energy density of lactating dairy cow diets. Products such as prilled hydrogenated fatty acids (FA) and Ca soaps of FA have been developed to limit the negative effects of FA on ruminal microflora and are generally considered as inert in the rumen (Grummer, 1988). However, FA from Ca soaps of FA are partially biohydrogenated in the rumen and this proportion increases with the level of FA unsaturation (Sukhija and Palmquist, 1990; Wu et al., 1991). The effect of these products on the fate of $\mathrm{B}$ vitamins in the rumen has never been studied. The present project aimed to evaluate if FS providing different proportions of SFA and UFA could change B-vitamin intake, apparent ruminal synthesis (ARS), and duodenal flow (DF) in dairy cows.

Feed and duodenal digesta samples were collected during a research project conducted at Michigan State 
University following approval by the Institutional Animal Care and Use Committee (Harvatine and Allen, 2006a). Eight multiparous Holstein cows from the Michigan State University Dairy Cattle Teaching and Research Center, equipped with rumen and duodenal cannulas and housed in tie-stalls, were randomly assigned at 77 (SD 8.7) DIM to treatment sequence in a replicated $4 \times 4$ Latin square design with 21 -d treatment periods. The 4 treatments were a control diet without FS and 3 diets with $2.5 \%$ additional FA from supplements containing (1) SFA (SAT; prilled, hydrogenated FA, Energy Booster 100, MS Specialty Nutrition, Dundee, IL), (2) an intermediate mixture of SFA and Ca soaps of UFA (INT), or (3) UFA (UNS; Ca soaps of partially unsaturated FA, Megalac-R, Church and Dwight Company Inc., Princeton, NJ; Harvatine and Allen, 2006a). All rations were offered as a TMR once daily $(0900 \mathrm{~h})$ at $115 \%$ of the expected intake. The forage-to-concentrate ratio (\% of DM) was 37:63. Corn and alfalfa silages were used as forages and their relative contribution to total NDF was 17\% (Table 1). Individual feed intake was recorded daily. From d 11 to 14 of each period, samples of all dietary ingredients were collected daily and mixed into a sample per period. Duodenal samples were collected every $9 \mathrm{~h}$ from d 12 to 14; then, these 8 samples were pooled per cow per period. All samples were stored at $-20^{\circ} \mathrm{C}$ before processing. Experimental procedures, measurements, and analyses were described in detail by Harvatine and Allen (2006a,b).

B-vitamin concentrations in feed and duodenal digesta were analyzed at the Sherbrooke Research and Development Centre (Agriculture and Agri-Food Canada, Sherbrooke, QC, Canada) as described by Castagnino et al. (2016b). Thiamine, riboflavin, niacin, and vitamin $\mathrm{B}_{6}$ were quantified by HPLC (Varian ProStar, Lake Forest, CA) equipped with a solvent delivery system (model 210), an autosampler (model 410), and a fluorescence detection system (model 363). Folates were determined with a microbiological microtiter plate test (VitaFast Folic Acid, R-Biopharm Inc., Marshall, MI) and vitamin $\mathrm{B}_{12}$ was analyzed by radio-assay [SimulTRAC-S Vitamin $\mathrm{B}_{12} \quad\left({ }^{57} \mathrm{Co}\right) / \mathrm{Fo}-$ late $\left({ }^{125} \mathrm{I}\right)$, MP Biomedicals, Solon, $\left.\mathrm{OH}\right]$. Dietary Co concentrations were determined by atomic absorption spectrometry with flame stoichiometric air-acetylene at $240.7 \mathrm{~nm}$ as described by Castagnino et al. (2016a). Samples were analyzed in duplicate (except for folates for which samples were analyzed in triplicate), and a coefficient of variation of less than $10 \%$ was accepted between replicates.

B-vitamin concentrations in the 4 experimental TMR were the summation of B-vitamin concentration in each ingredient multiplied by the proportion of this ingredi- ent in the TMR, on a DM basis. Daily intakes of each vitamin were calculated as the concentration of each vitamin in the TMR multiplied by DMI. Calculations of DM DF were described by Harvatine and Allen (2006a). B-vitamin DF was calculated as B-vitamin concentrations in duodenal sample multiplied by the daily DM flowing through the duodenum. Apparent ruminal synthesis was calculated as DF minus the daily intake of each vitamin. Total niacin daily intake, DF, and ARS were calculated as the sum of nicotinic acid and nicotinamide for these variables. Total daily intake, $\mathrm{DF}$, and ARS of vitamin $\mathrm{B}_{6}$ were calculated as the sum of pyridoxamine, pyridoxal, and pyridoxine for these variables.

Daily intake, DF, and ARS for each vitamin, expressed in milligrams per day or milligrams per kilogram of DMI, were analyzed using the MIXED procedure of SAS (version 9.4, SAS Institute Inc., 2012) in which period and treatment were considered as fixed effects and cow as a random effect. A priori contrasts, (1) effect of addition of FS (control vs. SAT, INT, and UNS), (2) linear effect of substituting UFA for SFA (SAT vs. UNS), and (3) quadratic effect of substituting UFA for SFA (INT vs. SAT and UNS), were used. Differences were declared significant at $P<0.05$ and as a tendency at $0.05 \leq P \leq 0.10$.

Daily DMI was 26.5, 25.4, 24.5, and 23.0 (SE 0.93) kg for control, SAT, INT, and UNS, respectively. Feeding FS decreased DMI in lactating dairy cows and DMI decreased linearly when increasing the proportion of UFA in FS (Harvatine and Allen, 2006a). Dry matter DF followed a similar trend (FS effect, $P=0.03$; linear effect, $P<0.001$ ), with 18.9, 19.4, 17.5, and 15.7 (SE 0.92) $\mathrm{kg}$ of $\mathrm{DM} / \mathrm{d}$ for control, SAT, INT, and UNS, respectively. B-vitamin concentrations were similar among the 4 experimental diets (Table 1 ). Consequently, daily intake of the studied vitamins, except for vitamin $\mathrm{B}_{12}$, followed the same pattern as DMI. Fat supplements decreased $(P \leq 0.001)$ B-vitamin intakes, which also decreased $(P \leq 0.03)$ linearly when the proportion of UFA increased (Table 2).

Fat supplements decreased (FS effect, $P=0.001$ ) the amount of vitamin $\mathrm{B}_{6}$ reaching the duodenum daily compared with control, and daily $\mathrm{DF}$ of vitamin $\mathrm{B}_{6}$ tended to decrease (linear effect, $P=0.07$ ) when increasing the proportion of UFA in the supplement (Table 2). However, when expressed per unit of DMI, FS decreased (FS effect, $P=0.04$ ) DF of vitamin $\mathrm{B}_{6}$ and tended to increase (FS effect, $P=0.08$ ) degradation of the vitamin in the rumen (Table 2). Treatments did not affect $(P \geq 0.20)$ the daily amounts of folates reaching the duodenum or their apparent synthesis in the rumen. However, when expressed per unit of DMI, FS increased folate DF and ARS (FS effect, $P$ 
Table 1. Ingredients, nutrient composition, and B-vitamin concentrations of the experimental diets ${ }^{1}$

\begin{tabular}{|c|c|c|c|c|}
\hline \multirow[b]{2}{*}{ Item } & \multicolumn{4}{|c|}{ Treatment $^{2}$} \\
\hline & Control & SAT & INT & UNS \\
\hline \multicolumn{5}{|l|}{ Ingredient, $\%$ of $\mathrm{DM}$} \\
\hline Corn silage $^{3}$ & 24.6 & 24.7 & 24.7 & 24.6 \\
\hline Alfalfa silage ${ }^{4}$ & 12.6 & 12.6 & 12.6 & 12.6 \\
\hline Ground corn & 28.7 & 28.8 & 28.8 & 28.7 \\
\hline Whole cottonseed & 13.5 & 13.5 & 13.5 & 13.5 \\
\hline Protein $\operatorname{mix}^{5}$ & 10.5 & 10.6 & 10.5 & 10.5 \\
\hline Mineral-vitamin $\operatorname{mix}^{6}$ & 4.3 & 4.3 & 4.3 & 4.3 \\
\hline Control $\operatorname{mix}^{7}$ & 5.7 & 0.5 & 0.2 & - \\
\hline SAT $\operatorname{mix}^{7}$ & - & 5.0 & 2.5 & - \\
\hline UNS $\operatorname{mix}^{7}$ & - & - & 2.9 & 5.7 \\
\hline \multicolumn{5}{|l|}{ Nutrient } \\
\hline DM, $\%$ as fed & 55.6 & 55.7 & 55.7 & 55.7 \\
\hline $\mathrm{OM}, \%$ of $\mathrm{DM}$ & 92.6 & 92.9 & 93.1 & 93.1 \\
\hline Total fatty acids, $\%$ of DM & 5.5 & 8.3 & 8.1 & 7.8 \\
\hline UFA, $\%$ of DM & 3.6 & 3.9 & 4.4 & 4.9 \\
\hline Starch, \% of DM & 30.8 & 30.3 & 30.5 & 30.7 \\
\hline $\mathrm{NDF}, \%$ of DM & 29.1 & 27.3 & 27.5 & 27.7 \\
\hline Indigestible NDF, \% of DM & 11.2 & 9.7 & 10.0 & 9.9 \\
\hline Forage NDF, \% of DM & 16.9 & 17.0 & 16.9 & 17.0 \\
\hline $\mathrm{CP}, \%$ of $\mathrm{DM}$ & 16.2 & 16.1 & 16.1 & 16.1 \\
\hline Rumen-undegraded $\mathrm{CP},{ }^{8} \%$ of DM & 5.1 & 4.8 & 5.1 & 4.9 \\
\hline Gross energy, Mcal $/ \mathrm{kg}$ & 4.55 & 4.72 & 4.72 & 4.71 \\
\hline Total cobalt, $\mathrm{mg} / \mathrm{kg}$ of $\mathrm{DM}$ & 1.34 & 1.33 & 1.13 & 1.17 \\
\hline \multicolumn{5}{|l|}{ B-vitamin concentration, $\mathrm{mg} / \mathrm{kg}$ of DM } \\
\hline Thiamine & 2.11 & 2.05 & 2.06 & 2.07 \\
\hline Riboflavin & 24.59 & 24.46 & 24.45 & 24.47 \\
\hline Niacin $^{9}$ & 28.79 & 28.60 & 28.35 & 28.13 \\
\hline Vitamin $\mathrm{B}_{6}{ }^{10}$ & 4.06 & 4.02 & 4.04 & 4.07 \\
\hline Folates & 0.37 & 0.34 & 0.35 & 0.35 \\
\hline Vitamin $B_{12}$ & $\mathrm{ND}^{11}$ & ND & ND & ND \\
\hline
\end{tabular}

${ }^{1}$ Adapted from Harvatine and Allen (2006a).

${ }^{2} \mathrm{SAT}=\mathrm{SFA}$ from prilled, hydrogenated fat (Energy Booster 100, MS Specialty Nutrition, Dundee, IL); INT $=$ mix of SAT and UNS; and UNS = Ca soaps of partially unsaturated fatty acid (Megalac-R, Church and Dwight Company Inc., Princeton, NJ).

${ }^{3}$ Corn silage contained $34.7 \% \mathrm{DM}$ (as fed) and $43.4 \% \mathrm{NDF}, 8.4 \% \mathrm{CP}, 10.7 \%$ indigestible NDF, $24.1 \%$ starch, and $4.8 \%$ ash on a DM basis.

${ }^{4}$ Alfalfa silage contained $36.3 \% \mathrm{DM}$ (as fed) and $48.1 \% \mathrm{NDF}, 16.2 \% \mathrm{CP}, 25.7 \%$ indigestible NDF, $2.6 \%$ starch, and 9.7 ash on a DM basis.

${ }^{5}$ Protein mix contained $74.1 \%$ soybean meal, $20.1 \%$ corn gluten meal, and $5.8 \%$ blood meal.

${ }^{6}$ Vitamin-mineral mix contained (DM basis) $12.7 \%$ sodium bicarbonate, $11.5 \%$ limestone, $5.5 \%$ salt, $2.2 \%$ trace mineral premix, $2.0 \%$ urea, $2.0 \%$ dicalcium phosphate, $0.6 \%$ vitamin $\mathrm{D}, 0.48 \%$ vitamin $\mathrm{A}, 0.12 \%$ vitamin $\mathrm{E}$, and $62.9 \%$ dry ground corn as a carrier. Analyzed Co: $5.83 \mathrm{mg} / \mathrm{kg}$ of DM.

${ }^{7}$ Control mix contained $50.5 \%$ rice hulls, $16.7 \%$ limestone, and $32.7 \%$ ground corn; SAT mix contained $50.5 \%$ prilled, hydrogenated fatty acids, $16.7 \%$ limestone, and $32.7 \%$ ground corn; and UNS mix contained $57.5 \% \mathrm{Ca}$ soaps of fatty acid, $10.9 \%$ rice hulls, and $31.6 \%$ ground corn.

${ }^{8}$ Estimated by using values from NRC (2001).

${ }^{9} \mathrm{Sum}$ of nicotinic acid and nicotinamide.

${ }^{10} \mathrm{Sum}$ of pyridoxamine, pyridoxal, and pyridoxine.

${ }^{11} \mathrm{ND}=$ not detected.

$\leq$ 0.003) compared with control and both folate $\mathrm{DF}$ and ARS increased linearly (linear effect, $P \leq 0.02$ ) with the proportion of UFA in the supplement. Under the present experimental conditions, neither DMI nor folate intake had an effect on the total amount of this vitamin available for absorption by the cow. Thiamine daily DF decreased linearly (linear effect, $P=0.04$ ) when increasing the proportion of UFA, but this effect was no longer significant when reported per unit of DMI $(P=0.81)$. As no treatment effect $(P \geq 0.16)$ was observed on thiamine ARS, the difference in DF was probably due to the greater vitamin intake (linear effect, $P=0.01$ ). Riboflavin and niacin DF and ARS, expressed as milligrams per day or milligrams per kilogram of DMI, were not affected by FS $(P \geq 0.25$; Table 2 ). However, increasing the proportion of UFA in the FS decreased $(P \leq 0.04)$ daily riboflavin and niacin DF and ARS. This effect was still present when reported 
CASTAGNINO ET AL.

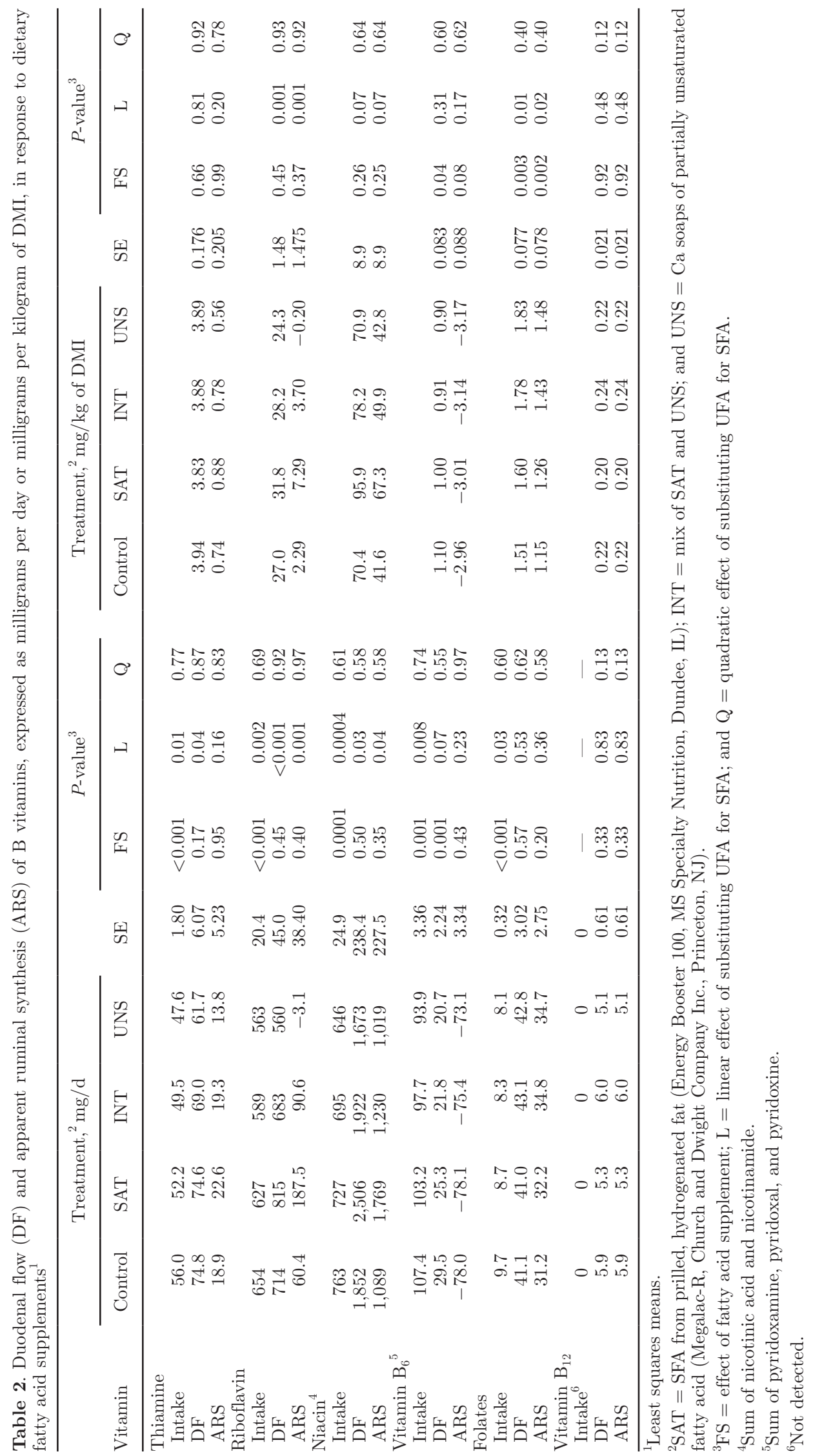


per unit of DMI $(P \leq 0.07$; Table 2$)$, suggesting that differences in ruminal conditions also affected the fate of these vitamins in the rumen. Neither DF nor ARS of vitamin $\mathrm{B}_{12}$, expressed as milligrams per day or milligrams per kilogram of DMI, were affected by FS or the proportion of UFA in the FS ( $P \geq 0.12$; Table 2$)$. Harvatine and Allen (2006a) observed a linear increase in ruminal digestibility of NDF when increasing the proportion of UFA in the supplements due to a slower passage rate of potentially digestible NDF, but a more rapid passage rate of indigestible NDF. Castagnino et al. (2016a) reported that riboflavin and niacin ARS are positively correlated with NDF digested in rumen and negatively correlated with indigestible NDF passage rate. Moreover, these authors observed that conditions promoting riboflavin and niacin ARS had the opposite effect on folate ARS.

Although the effects of the FA supplements on ruminal digestibility of NDF and its passage rate were attributed to physiological effects from greater DF of UFA (Harvatine and Allen, 2006b), these changes likely modified microbial activity in the rumen, which, in turn, altered the amounts of some B vitamins, especially riboflavin and niacin, available for the dairy cow.

\section{ACKNOWLEDGMENTS}

The authors thank Chrystiane Plante and Valérie Beaudet (Sherbrooke Research and Development Centre, Agriculture and Agri-Food Canada, Sherbrooke, QC, Canada) for their technical support. Vitamin analyses were financially supported by the Programme de recherche en partenariat pour l'innovation en production et transformation laitière Novalait, Agriculture et
Agroalimentaire Canada, Fonds de recherche du Québec Nature et Technologies, Ministère de l'Agriculture, des Pêcheries et de l'Alimentation du Québec, Québec, QC, Canada.

\section{REFERENCES}

Bechdel, S. I., H. E. Honeywell, R. A. Dutcher, and M. H. Knutsen. 1928. Synthesis of vitamin B in the rumen of the cow. J. Biol. Chem. 80:231-238.

Castagnino, D. S., K. L. Kammes, M. S. Allen, R. Gervais, P. Y. Chouinard, and C. L. Girard. 2016a. Particle length of silages affects apparent ruminal synthesis of B vitamins in lactating dairy cows. J. Dairy Sci. 99:6229-6236. https://doi.org/10.3168/jds.2016 -11274 .

Castagnino, D. S., M. Seck, V. Beaudet, K. L. Kammes, J. A. Voelker Linton, M. S. Allen, R. Gervais, P. Y. Chouinard, and C. L. Girard. 2016b. Effects of forage family on apparent ruminal synthesis of B vitamins in lactating dairy cows. J. Dairy Sci. 99:1884-1894. https://doi.org/10.3168/jds.2015-10319.

Grummer, R. R. 1988. Influence of prilled fat and calcium salt of palm oil fatty acids on ruminal fermentation and nutrient digestibility. J. Dairy Sci. 71:117-123. https://doi.org/10.3168/jds.S0022 $-0302(88) 79532-6$

Harvatine, K. J., and M. S. Allen. 2006a. Effects of fatty acid supplements on ruminal and total tract nutrient digestion in lactating dairy cows. J. Dairy Sci. 89:1092-1103. https://doi.org/10.3168/ jds.S0022-0302(06)72177-4.

Harvatine, K. J., and M. S. Allen. 2006b. Effects of fatty acid supplements on feed intake, and feeding and chewing behavior of lactating dairy cows. J. Dairy Sci. 89:1104-1112. https://doi.org/10 $.3168 /$ jds.S0022-0302(06)72178-6.

NRC. 2001. Nutrient Requirements of Dairy Cattle. 7 th rev. ed. Natl. Acad. Press, Washington, DC.

SAS Institute Inc. 2012. User's Guide: Statistics. Version 9.4. SAS Institute Inc., Cary, NC.

Sukhija, P. S., and D. L. Palmquist. 1990. Dissociation of calcium soaps of long-chain fatty acids in the rumen fluid. J. Dairy Sci. 73:1784-1787.

Wu, Z., O. A. Ohajuruka, and D. L. Palmquist. 1991. Ruminal synthesis, biohydrogenation, and digestibility of fatty acids by dairy cows. J. Dairy Sci. 74:3025-3034. 